\title{
Exploring the Perceptions of First-Year Engineering Students on Academic Dishonesty
}

\section{Lorena Peculea ${ }^{\bullet}$, Adrian Peculea ${ }^{\bullet}$}

\begin{abstract}
As part of a larger study on academic dishonesty, this paper aims to be a simple investigation of students' opinions on some ethical issues, such as cheating in exams and plagiarism in assignments. The main goal was to explore the level of awareness of cheating and plagiarism, the frequency of these dishonest behaviours, students' attitudes toward cheating and plagiarism and differences between demographic variables and the three dimensions mentioned above. This study was conducted through a questionnaire completed by 138 first-year engineering students at a university in Romania. The study showed that cheating and plagiarism practices are sometimes common among students; at the same time, it is necessary to increase students' awareness and attitudes in order to combat such misconduct. Also, students' ethical values and actions are in dissonance. The differences in gender and residence area of students are insignificant. The paper recommends that different actors collaborate to continuously educate and discourage students from engaging in academic dishonesty.
\end{abstract}

Keywords: cheating, plagiarism, awareness, behaviours, attitudes.

\section{Introduction}

The role of the university is to provide education to students, forming them intellectually, as well as contributing to the development of students' moral competences, as responsible citizens of the knowledge-based society. Thus, the first academic year is essential for students' entry into higher education, because a large amount of learning takes place differently by its nature and by the previous level experienced by these students. Then, this first academic year is the basis on which educational and professional success will be built.

As part of a large study, this research explores the perceptions of academic dishonesty, for example cheating and plagiarism, among first-year students at the Technical University of Cluj-Napoca, Romania. The specific objectives of this study were the following: to find out if students are aware of cheating and plagiarism; to determine the frequency of behaviours practiced by students regarding cheating and plagiarism; to

\footnotetext{
- Assistant PhD, Technical University of Cluj-Napoca, Specialized Department with Psycho-Pedagogical Profile, Cluj-Napoca, Romania, lorena.peculea@dppd.utcluj.ro

- Associate Professor PhD, Technical University of Cluj-Napoca, Faculty of Automation and Computer Science, Computer Science Department, Cluj-Napoca, Romania, adrian.peculea@cs.utcluj.ro
} 
identify students' attitudes towards cheating and plagiarism; to look for significant differences between demographic variables and the three dimensions mentioned above.

University members should understand the opinions about academic dishonesty expressed by students so that they can contribute to possible interventions to promote academic honesty practices among students. Thus, the study aims to contribute to the understanding of first-year students 'views on cheating and plagiarism in the educational institution where the research was conducted and, possibly, in other Romanian universities, to increase students' awareness and appreciation for academic integrity.

\section{Literature Review}

Academic integrity includes values, principles, norms and regulations for managing appropriate behaviours in education and research. The approaches in recent years which analysed the development of academic integrity include aspects related to university policies and supporting student learning (Bretag \& Mahmud, 2016), as well as the use of technology (Okada et al., 2019). Academic dishonesty is the opposite of academic integrity; it is characterized in various forms by which students show dishonesty in their university practices.

From the literature review, academic dishonesty can be grouped into three types: 1 ) cheating; 2) plagiarism; and 3) other incorrect academic behaviours. There is a growing interest in plagiarism as a result of the finding that it is an attack on the key values of academic integrity (e.g. Macfarlane, Zhang, \& Pun, 2014). Other researchers observe how cheating incidence remained high in recent years, despite the academic efforts to address this phenomenon (e.g. McCabe et al., 2012; Teixeira \& Rocha, 2010). Researchers argue that the factors that influence students 'misconduct are age, gender, academic level, form of assessment, course difficulty or cultural background (e.g. Teixeira \& Rocha, 2010). However, the significance of these factors appears to be dependent on the context. Also, ethical practice is central to the integrity of the engineering profession. The studies show that engineering students are among the most likely to involve in academic dishonesty in higher education (e.g. Carpenter, D.D. et al., 2010). Engineering institutions and faculty members play a key role in facilitating academic integrity among engineering students.

In the European project called IPPHEAE (Impact of Policies for Plagiarism in Higher Education across Europe), in which the state of academic integrity in educational institutions was analysed, all universities participating considered academic dishonesty as a critical problem, but also the fact that there were many examples of innovative practices (Glendinning et al. 2013). One of the few comprehensive studies on this topic (Foltýnek \& Glendinning, 2015) shows that Romania is ranked 4th in Europe by the rates of plagiarism. In Romania there are several studies that have shown high levels of acceptance of cheating and plagiarism among students (e.g. Ives et al., 2017). Recently, the Ministry of Education and Research (Order of the Ministry of National Education No. 3131/2018) decided to promote mandatory courses (both at the Master's Degree and Doctoral Degree) and optional courses (at the Bachelor's Degree) of ethics and academic 
integrity in all Romanian universities, a movement that has its origins in some public scandals about academic questionable moral values.

Consequently, studying awareness, behaviours and attitudes towards cheating and plagiarism can help students become aware of the dangers and consequences of engaging in academic dishonesty. At the same time, it can support teachers, institutions and decision makers to eliminate or, at least, to reduce the growing trend of dishonest conduct. To address this issue, the study aims to highlight what first-year students know about the terms "cheating" and "plagiarism" and to investigate perceptions about behaviours and attitudes towards the two unethical acts.

\section{Research methodology}

The main purpose of the study was to explore the opinions of first-year engineering students on cheating in tests/ exams and plagiarism in assignments. Understanding students' views on cheating and plagiarism can significantly help teachers to communicate appropriate rules and procedures.

The following basic research questions guided this study:

1. What is the level of awareness about cheating and plagiarism?

2. How often have first-year students practiced cheating during examination and plagiarism in assignments?

3. What is the attitude of students towards cheating and plagiarism?

4. Are there differences regarding gender and residence area of students on cheating and plagiarism awareness, their behaviours and attitudes towards cheating and plagiarism?

To assess perceptions of cheating and plagiarism by first-year engineering students of Technical University of Cluj-Napoca, a questionnaire was used as a tool for this study. A sample of 138 students - 56 (40.6\%) males and 82 (59.4\%) females - participated in this study; 57 subjects were enrolled in electrical profile, 45 students in building profile and 36 students in mechanical profile; 92 (66.7\%) students are from urban residence and $46(33.3 \%)$ students from rural residence.

The questionnaire is divided into two parts: the first includes the demographic information of the students, the second comprises the main part of the questionnaire. To investigate the level of awareness and attitudes towards cheating and plagiarism a 5point Likert scale was used from 1 ("strongly agree") to 5 ("strongly disagree"). The frequency of students' behaviours was measured on a 5-point Likert scale from "always" (1) to "never" (5). Some items (from 1 to 11 ) related to attitudes towards cheating and plagiarism were taken and adapted from the study of Amua-Sekyi and Mensah (2016). The results for the whole questionnaire showed that the internal consistency was $\alpha=$ 0.780 .

The study data were collected at the beginning of the second semester of the 20192020 academic year. The confidentiality of the respondents was guaranteed, and the questionnaire was completed "incognito", without identifying information. 


\section{Results}

The quantitative data are presented descriptively, using statistical analyses to examine the distribution of responses where the problems arising from the data deserve to be highlighted. Thus, the results are presented as tables and accompanied by comments.

Regarding the first category of questions aiming to explore the level of cheating and plagiarism awareness, respondents were asked to select their option on a scale from "strongly agree" to "strongly disagree" on 11 statements. The two columns showing agreement and the two columns showing disagreement were grouped into broader categories such as "agree" and "disagree". Thus, the highest awareness (M = 1.36, SD = 0.615 ) was found on the statement "I understand the meaning of plagiarism" followed by "Plagiarism is unethical and wrong conduct" with mean value as 1.56 , whereas the lowest awareness $(\mathrm{M}=2.53, \mathrm{SD}=0.960)$ was observed with regards to "The faculty is effective in detecting students who cheat". Table 1 depicts that only $76.8 \%$ of respondents and $81.2 \%$ of respondents know the conceptual meanings of the terms "cheating", respectively "plagiarism".

Table 1. Awareness of cheating and plagiarism

\begin{tabular}{|c|c|c|c|c|c|c|}
\hline No. & Statements & $\begin{array}{c}\text { Agree } \\
\text { No. }(\%)\end{array}$ & $\begin{array}{l}\text { Unsure } \\
\text { No. }(\%)\end{array}$ & $\begin{array}{l}\text { Disagree } \\
\text { No. }(\%)\end{array}$ & Mean & $S D$ \\
\hline 1 & I understand the meaning of cheating. & $120(87)$ & $12(8.7)$ & $6(4.3)$ & 1.71 & 0.803 \\
\hline 2 & Cheating on tests/ exams is an incorrect act. & $118(85.5)$ & $16(11.6)$ & $4(2.9)$ & 1.73 & 0.776 \\
\hline 3 & $\begin{array}{l}\text { Intentional violation of the rules in order to obtain } \\
\text { incorrect benefits or better school results in exams or } \\
\text { other forms of evaluation means cheating. }\end{array}$ & $106(76.8)$ & $12(8.7)$ & $20(14.5)$ & 1.94 & 1.131 \\
\hline 4 & I understand the meaning of plagiarism. & $128(92.8)$ & $10(7.2)$ & 0 & 1.36 & 0.615 \\
\hline 5 & Plagiarism is unethical and wrong conduct. & $126(91.3)$ & $8(5.8)$ & $4(2.9)$ & 1.56 & 0.791 \\
\hline 6 & $\begin{array}{l}\text { Using one's work (copying, paraphrasing, summarizing), } \\
\text { intentionally or unintentionally, as one's own work, } \\
\text { without mentioning the source and quoting it means } \\
\text { plagiarism. }\end{array}$ & $112(81.2)$ & $16(11.6)$ & $10(7.2)$ & 1.71 & 0.983 \\
\hline 7 & $\begin{array}{l}\text { I know the consequences of cheating and plagiarism in } \\
\text { academia. }\end{array}$ & $126(91.3)$ & $10(7.2)$ & $2(1.5)$ & 1.63 & 0.682 \\
\hline 8 & $\begin{array}{l}\text { The university has clear regulations regarding cheating } \\
\text { on tests/ exams and plagiarism in assignments. }\end{array}$ & $120(87)$ & $18(13)$ & 0 & 1.65 & 0.700 \\
\hline 9 & The faculty is effective in detecting students who cheat. & $70(50.7)$ & $48(34.8)$ & $20(14.5)$ & 2.53 & 0.960 \\
\hline 10 & $\begin{array}{l}\text { The faculty is effective in detecting students who } \\
\text { plagiarize. }\end{array}$ & $70(50.7)$ & $54(39.2)$ & $14(10.1)$ & 2.42 & 0.942 \\
\hline 11 & $\begin{array}{l}\text { University is effective in punishing students who cheat } \\
\text { and plagiarize. }\end{array}$ & $88(63.8)$ & $36(26.1)$ & $14(10.1)$ & 2.34 & 0.917 \\
\hline
\end{tabular}

Asked if the university has clear regulations regarding cheating and plagiarism, more than half of students (87\%) responded that they were aware of university's policies regarding cheating and plagiarism. Asked if the faculty was effective at catching students who cheat, a total of $50.7 \%$ of respondents answered agree; they gave a similar answer in case of catching students who plagiarize. These answers show that almost half of the students do not know or are not aware of their faculty effectiveness in identifying cases of cheating and plagiarism.

Table 2 indicate the frequency of cheating and plagiarism behaviours of students. Asked how often colleagues have used cheating and plagiarism in the last six months, 
first-year students responded saying that sometimes their colleagues used the crib notes, handwriting, sheets with written resolutions etc. during a test or exam (52.2\%) or whispered and signalled answers to someone (46.4\%). The highest mean $(\mathrm{M}=2.82, \mathrm{SD}=$ 1.066) was found on the statement "Copying the answers from a colleague's work during a test or exam", whereas the lowest mean $(M=4.85, S D=0.460)$ was observed with regards to "Taking tests or exams instead of another person". A frequency count on the unauthorized using of electronic devices during a test or exam found that it appears to be a common practice sometimes (33.3\%) and often (14.5\%) among students. Most students said they had never reported their colleagues for cheating $(76.8 \%)$ and for plagiarism $(75.4 \%)$.

Table 2. Cheating and plagiarism behaviours

\begin{tabular}{|c|c|c|c|c|c|c|c|c|}
\hline No & Behaviours & $\begin{array}{l}\text { Always } \\
\text { No. }(\%)\end{array}$ & $\begin{array}{c}\text { Often } \\
\text { No. (\%) }\end{array}$ & $\begin{array}{l}\text { Sometime } \\
\quad \text { S } \\
\text { No. }(\%)\end{array}$ & $\begin{array}{c}\text { Rarely } \\
\text { No. (\%) }\end{array}$ & $\begin{array}{c}\text { Never } \\
\text { No. (\%) }\end{array}$ & $\begin{array}{c}M e a \\
n\end{array}$ & $S D$ \\
\hline 1 & $\begin{array}{l}\text { Using unauthorized material (crib } \\
\text { notes, handwriting, sheets with } \\
\text { written resolutions etc.) during a test } \\
\text { or exam. }\end{array}$ & $4(2.9)$ & $\begin{array}{c}16 \\
(11.6)\end{array}$ & $72(52.2)$ & $\begin{array}{c}34 \\
(24.6)\end{array}$ & $\begin{array}{c}12 \\
(8.7)\end{array}$ & 3.24 & $\begin{array}{c}0.87 \\
8\end{array}$ \\
\hline 2 & $\begin{array}{l}\text { Copying the answers from a } \\
\text { colleague's work during a test or } \\
\text { exam. }\end{array}$ & $\begin{array}{c}14 \\
(10.1)\end{array}$ & $\begin{array}{c}44 \\
(31.9)\end{array}$ & $38(27.6)$ & $\begin{array}{c}36 \\
(26.1)\end{array}$ & $6(4.3)$ & 2.82 & $\begin{array}{c}1.06 \\
6\end{array}$ \\
\hline 3 & $\begin{array}{l}\text { Unauthorized using of electronic } \\
\text { devices (mobile phone, computer, } \\
\text { headset, smartwatch etc.) during a } \\
\text { test or exam. }\end{array}$ & $12(8.7)$ & $\begin{array}{c}20 \\
(14.5)\end{array}$ & 46 (33.3) & $\begin{array}{c}44 \\
(31.9)\end{array}$ & $\begin{array}{c}16 \\
(11.6)\end{array}$ & 3.23 & $\begin{array}{c}1.10 \\
9\end{array}$ \\
\hline 4 & $\begin{array}{l}\text { Whispering and signalling answers to } \\
\text { other colleagues during a test or } \\
\text { exam. }\end{array}$ & $6(4.3)$ & $\begin{array}{c}24 \\
(17.4)\end{array}$ & $64(46.4)$ & $\begin{array}{c}34 \\
(24.7)\end{array}$ & $\begin{array}{c}10 \\
(7.2)\end{array}$ & 3.13 & $\begin{array}{c}0.93 \\
4\end{array}$ \\
\hline 5 & $\begin{array}{l}\text { Allowing another person to copy } \\
\text { from them during a test or exam. }\end{array}$ & $10(7.2)$ & $\begin{array}{c}20 \\
(14.5) \\
\end{array}$ & $36(26.1)$ & $\begin{array}{c}54 \\
(39.2) \\
\end{array}$ & $18(13)$ & 3.36 & $\begin{array}{c}1.10 \\
6 \\
\end{array}$ \\
\hline 6 & $\begin{array}{l}\text { Failure to follow the instructions } \\
\text { related to the test or exam time (e.g. } \\
\text { continuing to write after the allotted } \\
\text { time has ended). }\end{array}$ & $4(2.9)$ & $\begin{array}{c}24 \\
(17.4)\end{array}$ & $12(8.7)$ & $\begin{array}{c}60 \\
(43.5)\end{array}$ & $\begin{array}{c}38 \\
(27.5)\end{array}$ & 3.75 & $\begin{array}{c}1.12 \\
5\end{array}$ \\
\hline 7 & $\begin{array}{l}\text { Taking tests or exams instead of } \\
\text { another person. }\end{array}$ & 0 & $2(1.5)$ & 0 & $\begin{array}{c}14 \\
(10.1)\end{array}$ & $\begin{array}{c}122 \\
(88.4)\end{array}$ & 4.85 & $\begin{array}{c}0.46 \\
0\end{array}$ \\
\hline 8 & $\begin{array}{l}\text { Reproducing a test or exam questions } \\
\text { and sharing them with friends. }\end{array}$ & $8(5.8)$ & $\begin{array}{c}10 \\
(7.2) \\
\end{array}$ & $26(18.9)$ & $\begin{array}{c}30 \\
(21.7) \\
\end{array}$ & $\begin{array}{c}64 \\
(46.4) \\
\end{array}$ & 3.95 & $\begin{array}{c}1.21 \\
3\end{array}$ \\
\hline 9 & $\begin{array}{l}\text { Finding an excuse to temporarily } \\
\text { leave the exam room in order to have } \\
\text { access to outside help. }\end{array}$ & $2(1.5)$ & $6(4.3)$ & $28(20.3)$ & $\begin{array}{c}50 \\
(36.2)\end{array}$ & $\begin{array}{c}52 \\
(37.7)\end{array}$ & 4.04 & $\begin{array}{c}0.94 \\
2\end{array}$ \\
\hline 10 & $\begin{array}{l}\text { Reporting cheating practiced by a } \\
\text { colleague. }\end{array}$ & 0 & $2(1.5)$ & $6(4.3)$ & $\begin{array}{c}24 \\
(17.4) \\
\end{array}$ & $\begin{array}{c}106 \\
(76.8)\end{array}$ & 4.69 & $\begin{array}{c}0.62 \\
3\end{array}$ \\
\hline 11 & $\begin{array}{l}\text { Presenting a work as its own that has } \\
\text { been copied, in whole or in part, from } \\
\text { the Internet or from another source } \\
\text { without using proper citation. }\end{array}$ & $2(1.5)$ & $\begin{array}{c}14 \\
(10.1)\end{array}$ & $26(18.9)$ & $\begin{array}{c}38 \\
(27.5)\end{array}$ & $58(42)$ & 3.98 & $\begin{array}{c}1.07 \\
3\end{array}$ \\
\hline 12 & $\begin{array}{l}\text { Writing a work for friends which uses } \\
\text { as its own work. }\end{array}$ & 0 & $\begin{array}{c}10 \\
(7.2)\end{array}$ & 40 (29) & $\begin{array}{c}32 \\
(23.2)\end{array}$ & $\begin{array}{c}56 \\
(40.6)\end{array}$ & 3.97 & $\begin{array}{c}0.99 \\
5\end{array}$ \\
\hline 13 & $\begin{array}{l}\text { Presenting a work as its own that has } \\
\text { been written/ completed, in whole or } \\
\text { in part, by others (colleagues, } \\
\text { companies/ specialized sites etc.). }\end{array}$ & $2(1.5)$ & $\begin{array}{c}14 \\
(10.1)\end{array}$ & $22(15.9)$ & $\begin{array}{c}38 \\
(27.5)\end{array}$ & $62(45)$ & 4.04 & $\begin{array}{c}1.07 \\
3\end{array}$ \\
\hline 14 & $\begin{array}{l}\text { Reporting plagiarism practiced by a } \\
\text { colleague. }\end{array}$ & 0 & 0 & $10(7.2)$ & $\begin{array}{c}24 \\
(17.4)\end{array}$ & $\begin{array}{c}104 \\
(75.4)\end{array}$ & 4.68 & $\begin{array}{c}0.60 \\
3\end{array}$ \\
\hline
\end{tabular}


Table 3 presents the third category of questions aimed at exploring students' attitudes towards cheating and plagiarism.

Table 3. Attitudes towards cheating and plagiarism

\begin{tabular}{|c|c|c|c|c|c|c|}
\hline No. & Statements & $\begin{array}{c}\text { Agree } \\
\text { No. }(\%)\end{array}$ & $\begin{array}{l}\text { Unsure } \\
\text { No. }(\%)\end{array}$ & $\begin{array}{l}\text { Disagree } \\
\text { No. }(\%)\end{array}$ & Mean & $S D$ \\
\hline 1 & I would cheat if the exam questions were too difficult. & $58(42)$ & $28(20.3)$ & $52(37.7)$ & 2.94 & 1.242 \\
\hline 2 & I would cheat to obtain a higher grade. & $50(36.2)$ & $28(20.3)$ & $60(43.5)$ & 3.10 & 1.222 \\
\hline 3 & I would cheat to avoid failure. & $64(46.4)$ & $18(13)$ & $56(40.6)$ & 2.95 & 1.201 \\
\hline 4 & I would cheat so as not to disappoint my family. & $34(24.6)$ & $34(24.7)$ & $70(50.7)$ & 3.27 & 1.265 \\
\hline 5 & $\begin{array}{l}\text { I would cheat if other colleagues in my year/ group } \\
\text { did the same thing. }\end{array}$ & $24(17.4)$ & $38(27.5)$ & $76(55.1)$ & 3.57 & 1.086 \\
\hline 6 & I would cheat if the teacher did not teach well. & $58(42)$ & $28(20.3)$ & $52(37.7)$ & 2.97 & 1.312 \\
\hline 7 & I would cheat if there was too much work. & $26(18.8)$ & $44(31.9)$ & $68(49.3)$ & 3.40 & 1.084 \\
\hline 8 & $\begin{array}{l}\text { It is wrong to cheat, even if the course content is } \\
\text { difficult. }\end{array}$ & $108(78.3)$ & $18(13)$ & $12(8.7)$ & 1.91 & 0.977 \\
\hline 9 & $\begin{array}{l}\text { It is wrong to cheat, even if the teacher gives you too } \\
\text { much work. }\end{array}$ & $118(85.5)$ & $14(10.2)$ & $6(4.3)$ & $\mathbf{1 . 8 1}$ & 0.841 \\
\hline 10 & $\begin{array}{l}\text { It is wrong to cheat, even if I am in danger of failing } \\
\text { the exams. }\end{array}$ & $96(69.6)$ & $30(21.7)$ & $12(8.7)$ & 2.02 & 1.010 \\
\hline 11 & It is wrong to cheat, regardless of the circumstances. & $98(71)$ & $32(23.2)$ & $8(5.8)$ & 1.89 & 0.998 \\
\hline 12 & $\begin{array}{l}\text { I would report the incidence of cheating committed by } \\
\text { an unknown student. }\end{array}$ & $2(1.5)$ & $30(21.7)$ & $106(76.8)$ & 4.07 & 0.770 \\
\hline 13 & $\begin{array}{l}\text { I would report the incidence of cheating committed by } \\
\text { a friend student. }\end{array}$ & 0 & $32(23.2)$ & $106(76.8)$ & 4.14 & 0.769 \\
\hline 14 & I would plagiarize if I knew I would not be caught. & $14(10.2)$ & $46(33.3)$ & $78(56.5)$ & 3.62 & 1.012 \\
\hline 15 & $\begin{array}{l}\text { I would plagiarize if I did not have enough time to do } \\
\text { the work. }\end{array}$ & $26(18.8)$ & $38(27.5)$ & $74(53.7)$ & 3.46 & 1.061 \\
\hline 16 & $\begin{array}{l}\text { I would plagiarize if I did not know how to quote, } \\
\text { how to mention references. }\end{array}$ & $16(11.6)$ & $32(23.2)$ & $90(65.2)$ & 3.66 & 0.991 \\
\hline 17 & $\begin{array}{l}\text { I would plagiarize if I knew that severe sanctions } \\
\text { would not apply. }\end{array}$ & $12(8.7)$ & $24(17.4)$ & $102(73.9)$ & 3.84 & 0.930 \\
\hline 18 & $\begin{array}{l}\text { I would plagiarize because it is easy to copy and } \\
\text { insert from the Internet. }\end{array}$ & $14(10.1)$ & $28(20.3)$ & $96(69.6)$ & 3.76 & 0.953 \\
\hline 19 & $\begin{array}{l}\text { I would plagiarize if I knew the teacher would not } \\
\text { care. }\end{array}$ & $32(23.2)$ & $30(21.7)$ & $76(55.1)$ & 3.43 & 1.177 \\
\hline 20 & $\begin{array}{l}\text { I would plagiarize to accomplish the task and get a } \\
\text { better grade. }\end{array}$ & $24(17.4)$ & $34(24.6)$ & $80(58)$ & 3.52 & 1.088 \\
\hline 21 & $\begin{array}{l}\text { I would plagiarize when I could not express another } \\
\text { person's ideas in my own words. }\end{array}$ & $24(17.4)$ & $26(18.8)$ & $88(63.8)$ & 3.57 & 1.086 \\
\hline 22 & $\begin{array}{l}\text { I would plagiarize if I knew a colleague was also } \\
\text { plagiarizing. }\end{array}$ & $4(2.9)$ & $20(14.5)$ & $114(82.6)$ & 4.13 & 0.869 \\
\hline 23 & $\begin{array}{l}\text { I would plagiarize because it is easier than working on } \\
\text { a topic. }\end{array}$ & $8(5.8)$ & $18(13)$ & $112(81.2)$ & 4.04 & 0.861 \\
\hline 24 & $\begin{array}{l}\text { It is wrong to plagiarize, even if I do not understand } \\
\text { the subject matter or the teacher's instructions. }\end{array}$ & $112(81.2)$ & $14(10.1)$ & $12(8.7)$ & 1.92 & 0.940 \\
\hline 25 & $\begin{array}{l}\text { It is wrong to plagiarize, even if I do not pay } \\
\text { importance to the idea of intellectual property. }\end{array}$ & $112(81.2)$ & $18(13)$ & $8(5.8)$ & 1.95 & 0.911 \\
\hline 26 & $\begin{array}{l}\text { It is wrong to plagiarize, regardless of the } \\
\text { circumstances. }\end{array}$ & $106(76.8)$ & $22(16)$ & $10(7.2)$ & 1.92 & 1.001 \\
\hline 27 & $\begin{array}{l}\text { I would report the incidence of plagiarism committed } \\
\text { by an unknown student. }\end{array}$ & $8(5.8)$ & $34(24.6)$ & $96(79.6)$ & 3.98 & 0.912 \\
\hline 28 & $\begin{array}{l}\text { I would report the incidence of plagiarism committed } \\
\text { by a friend student. }\end{array}$ & $6(4.3)$ & $32(23.2)$ & $100(72.5)$ & 4.02 & 0.870 \\
\hline
\end{tabular}

Mean of means $=3.18$

The majority of respondents agreed that "It is wrong to cheat even if the teacher gives you too much work" ( $\mathrm{M}=1.81, \mathrm{SD}=0.841)$; similarly, most respondents agreed that "It is wrong to cheat even if the course content is difficult" (78.3\%) or "It is wrong to cheat, regardless of the circumstances" (71\%). A large majority disagreed that they would 
report the incidence of cheating committed by an unknown student or by a friend student (76.8\%). Most of respondents (81.2\%) opted that they consider it is wrong to plagiarize, even if they do not understand the subject matter or the teacher's instructions; similarly, the majority agreed that it is wrong to plagiarize, even if they do not pay importance to the idea of intellectual property. More than half of respondents agreed that it is wrong to plagiarize, regardless of the circumstances (76.8\%). A large majority of students disagreed that they would report the incidence of plagiarism committed by an unknown student $(79.6 \%)$. Also, 32 (23.2\%) respondents agreed that they would plagiarize if they knew the teacher would not care.

Then, we hypothesize that gender and residence area of students do not influence cheating and plagiarism awareness, cheating and plagiarism behaviours and students' attitude towards cheating and plagiarism. Statistical results of two separate independent sample t-tests are shown in Table 4 and Table 5.

Table 4. Descriptive statistics for $t$-test according to the gender

\begin{tabular}{lccccccc}
\hline & Gender & $N$ & Mean & $S D$ & $t$ & $d f$ & $\begin{array}{c}\text { Sig }(2- \\
\text { tailed }\end{array}$ \\
\hline Cheating and plagiarism & Male & 56 & 1.928 & 0.471 & 1.193 & 136 & .235 \\
awareness & Female & 82 & 1.838 & 0.412 & & & .033 \\
\hline Cheating and plagiarism & Male & 56 & 3.969 & 0.601 & 2.154 & 136 & \\
behaviours & Female & 82 & 3.754 & 0.557 & & & .023 \\
\hline Attitude towards cheating & Male & 56 & 3.077 & 0.406 & -2.306 & 136 & .023 \\
and plagiarism & Female & 82 & 3.247 & 0.435 & & & \\
\hline
\end{tabular}

The results show that there are slight differences between the means of male and female students on cheating and plagiarism awareness $\left(M_{\text {male }}=1.92, M_{\text {female }}=1.83\right)$, on their cheating and plagiarism behaviours $\left(\mathrm{M}_{\text {male }}=3.96, \mathrm{M}_{\text {female }}=3.75\right)$ and on attitudes towards cheating and plagiarism $\left(\mathrm{M}_{\text {male }}=3.07\right.$, $\left.\mathrm{M}_{\text {female }}=3.24\right)$. The mean for the values of cheating and plagiarism behaviours for male students is significantly higher $(t=2.154$, df $=136$, two-tailed $p=0.033$ ) than that of female students. In other words, male students are more likely to practice less unethical behaviours compared to female students. There are statistically significant differences in scores between male and female students $[\mathrm{t}(136)=-2.306, \mathrm{p}<0.05]$ on their attitudes towards cheating and plagiarism. There are no statistically significant differences in scores between male and female students on cheating and plagiarism awareness. Calculating the effect size, according to Cohen's criteria, differences between genders are small with values below 0.2 . Thus, we conclude that gender has a low level of influence on behaviours and attitudes towards cheating and plagiarism. We admit the hypothesis that students' gender does not influence cheating and plagiarism awareness.

In Table 5 the results indicate the differences of means between the urban and rural residence of students on cheating and plagiarism awareness $\left(\mathrm{M}_{\text {urban }}=1.91, \mathrm{M}_{\text {rural }}=1.79\right)$, cheating and plagiarism behaviours ( $\mathrm{Murban}_{2}=3.76$, Mrural $=3.98$ ) and students' attitudes towards cheating and plagiarism $\left(\mathrm{M}_{\text {urban }}=3.13, \mathrm{M}_{\text {rural }}=3.27\right)$. Additional analysis was performed to test for statistically significant differences. 
Table 5. Descriptive statistics for $t$-test according to the residence area

\begin{tabular}{|c|c|c|c|c|c|c|c|}
\hline & Residence area & $N$ & Mean & $S D$ & $t$ & $d f$ & $\begin{array}{l}\text { Sig }(2- \\
\text { tailed })\end{array}$ \\
\hline \multirow{2}{*}{$\begin{array}{l}\text { Cheating and plagiarism } \\
\text { awareness }\end{array}$} & Urban & 92 & 1.917 & 0.420 & \multirow[t]{2}{*}{1.608} & \multirow[t]{2}{*}{136} & \multirow[t]{2}{*}{.110} \\
\hline & Rural & 46 & 1.790 & 0.465 & & & \\
\hline \multirow{2}{*}{$\begin{array}{l}\text { Cheating and plagiarism } \\
\text { behaviours }\end{array}$} & Urban & 92 & 3.768 & 0.624 & \multirow[t]{2}{*}{-2.317} & \multirow[t]{2}{*}{116.161} & \multirow[t]{2}{*}{.022} \\
\hline & Rural & 46 & 3.987 & 0.464 & & & \\
\hline \multirow{2}{*}{$\begin{array}{l}\text { Attitude towards cheating and } \\
\text { plagiarism }\end{array}$} & Urban & 92 & 3.131 & 0.412 & \multirow[t]{2}{*}{-1.842} & \multirow[t]{2}{*}{136} & \multirow[t]{2}{*}{.068} \\
\hline & Rural & 46 & 3.273 & 0.455 & & & \\
\hline
\end{tabular}

According to the obtained results, there were statistically significant differences in cheating and plagiarism behaviours [ $\mathrm{t}(116.161)=-2.317, \mathrm{p}<0.05)]$. Thus, students from rural residence obtain on average significantly higher scores at cheating and plagiarism behaviours compared to students from urban residence. In other words, rural students are more likely to practice less unethical behaviours compared to urban students. There are no statistically significant differences in scores between urban and rural residence of students on cheating and plagiarism awareness and students' attitudes towards cheating and plagiarism. Calculating the effect size according to Cohen's criteria, differences between residence areas are insignificant with values below 0.2 . Thus, we conclude that residence area has a very low level of influence on cheating and plagiarism behaviours. We admit the hypothesis that the students' residence area does not influence cheating and plagiarism awareness and students' attitudes towards cheating and plagiarism.

\section{Discussions}

This study aimed to investigate the level of awareness, behaviours and attitudes regarding cheating on tests/ exams and plagiarism in assignments as misconduct of academic integrity.

The research has shown that most first-year students are aware of what cheating and plagiarism mean. Moreover, the students are aware of the existing university regulations regarding academic dishonesty. However, it is necessary to make students aware that their faculty is effective to detect cheating and plagiarism, so that academic dishonesty is not tolerated. The results speak about the effectiveness of the values and ethics system of the faculties in the students' minds. Faculty management needs to design and coordinate the ethical education programs for students in order to directly influence the development of students, their attitudes and to strengthen the integrity of students. According to ethics management in organizations, in order to create a moral university, it needs to internalize a series of organizational virtues in all its practices and processes so as to stimulate the academic community members to behave ethically (Kaptein, M., 1998).

Specifically, teachers have more work to ensure that students not only know that there are university regulations on academic dishonesty, but also respect them. In order to increase academic integrity, teachers should emphasize the importance of integrity in 
the learning process, such as: informing on the university policy and the relevance of academic honesty in the classroom and in the papers; debating significant integrity issues for the course, but also for the future professions of the students; reminding integrity rules before exams; learning to recognize the signs of stress at students; developing a good relationship between teachers and their students; discussing learning styles and raising self-awareness; helping to manage time efficiently; emphasizing the real usefulness of knowledge and skills; stressing the importance of deep learning rather than memorization; asking for help from students to create a climate of integrity in the classroom; carefully designing of authentic, innovative and meaningful assessments etc.). Some possibilities for optimizing the evaluation are suggested by O. S. Bersan (2019): ensuring the combination of feedback and feedforward, emphasizing assessment for learning, optimizing assessment strategies, including the maximum use of the online environment for assessment purposes. On the other hand, in order to avoid any confusion on understanding of what exactly cheating and plagiarism mean and how to avoid them, it is therefore necessary that expectations of academic integrity be communicated explicitly, directly and repeatedly. Allocating a considerable place to cheating and plagiarism in educational programs, with a focus on prevention rather than penalties, emphasizing the significance of academic integrity and developing the moral character of university members need to be part of university policy. Therefore, in order to deter cheating and plagiarism, faculty must establish a solid policy, inform students of this policy and enforce the policy with strict consequences.

Despite students' awareness about cheating and plagiarism, the findings suggest that the two unethical conduct are sometimes common among first-year students. Thus, the students' knowledge that there are regulations on academic dishonesty, does not act as a deterrent to the problem. The results show that there are remarkable differences in what students consider to be wrong and the frequency of cheating and plagiarism in which they are involved. Thus, students' ethical values and their actions are dissonant. The Internet and technology offer very generous conditions for intensifying cheating and plagiarism. Either the use of technology and the internet takes place in the examination room or outside it, or in assessments some students use mobile phones, headset, smartwatches, social networks or use hacking to access online solutions, it is obvious that digital natives are often more skilled in technology than some of their teachers. With the help of technological means and educational actions, teachers can limit the possibilities of cheating and plagiarism. Thus, by understanding as much as possible of engaging students in acts of academic dishonesty, institutions can use or develop effective means of detecting and combating cheating and plagiarism. Tools such as Turnitin or iThenticate can be used to enhance students' academic writing skills and to develop their citation skills. Moreover, the use of systems for student authentication and authorship verification, tools for automatic logging and locked browsers, complete online surveillance systems, content analysis software systems for authorship checking or biometric systems are other solutions proposed in the literature or practice to support 
the detection and prevention of cheating and plagiarism using technologies in assessment activities. Although technology plays a major role in academic misconduct, older methods of cheating cannot be neglected as they are still used today. The most participants perceive copying from crib notes, mobile phones or other ways as unethical acts; however, they will not report their colleagues because it contradicts the ethics of peer loyalty. Therefore, it is necessary to consider students' perceptions of cheating and plagiarism because their views on the behaviour of their peers have a strong effect on their own behaviour. These findings must be considered in relation to the study of Rettinger and Kramer's (2009), which showed that "when students believe others have cheated, they are more likely to choose to cheat themselves".

Students' attitudes towards cheating and plagiarism appear to be neutral. Changing student behaviour can not only be the responsibility of higher education institutions, but also of students' families and even society as a whole. From the results, it seems that the students consider that plagiarism is less serious than cheating during an examination, because plagiarism does not take place directly during the examination or it is more difficult to detect it, so the source of the information remains unknown. It is thus necessary for educational institutions not only to increase awareness and understanding of cheating and plagiarism and the techniques used in them, but also to increase over time students' attitudes towards honest academic practices. This means constantly organizing courses, seminars, workshops or symposia on the meanings, reasons, types, consequences, techniques or tools for detecting and avoiding cheating and plagiarism.

This research has limitations, including the fact that all of these students were firstyear students who probably haven't yet written a paper at the faculty level or have taken only a few final semester exams; it was restricted only to awareness, behaviours and attitudes towards cheating and plagiarism; research referred to examinations and other assessment processes. However, the most important implication of this study is that teachers and students should engage in extensive conversations about academic dishonesty that encompasses a wide range of behaviours and to promote academic honesty practices among students. Although cheating and plagiarism may not be eliminated, it is still possible for teachers to educate their students and build assessment tasks so that cheating, and plagiarism are greatly reduced.

\section{Conclusions}

Concerned about the frequency of cheating and plagiarism behaviours among students, this paper sampled first-year engineering students through a questionnaire that focused on awareness, practices and attitudes towards cheating and plagiarism. The results found that although almost three quarters of the students are aware that cheating and plagiarism are unethical practices, they would continue to be involved in cheating and plagiarism during examinations or assignments. Thus, students' ethical beliefs and their actions are in dissonance. The study showed that cheating and plagiarism practices are sometimes common among some students and that they express neutral attitudes 
towards the two unethical acts. Thus, the findings of this study recommended that university and faculties should increase appreciation for academic integrity and allocate resources to prevent and combat cheating and plagiarism.

Any credible university should be fully committed to the ideal of renowned schooling, excellence in education and research with national and international recognition and legitimacy. Academic integrity is a precondition for achieving this ambitious ideal.

\section{References}

Amua-Sekyi, E.T. \& Mensah, E. (2016). Guilty in Whose Eyes? Student-Teachers' Perspectives on Cheating on Examinations. Journal of Education and Practice, 7 (21), 55-64.

Bersan, O. S. (2019). Evaluarea în educația adulților. In Sava, S., Paloș, R. (coord.), Educația adulților. Baze teoretice și repere practice. Editura Polirom. Iași, 247-249.

Bretag, T., Mahmud, S. (2016). A conceptual framework for implementing exemplary academic integrity policy in Australian higher education. In T.A. Bretag (ed), Handbook of Academic Integrity. Springer Singapore, Singapore, 463-480.

Carpenter, D., Harding, T., \& Finelli, C. (2010). Using research to identify academic dishonesty deterrents among engineering undergraduates. International Journal of Engineering Education, 26(5), 11561165.

Foltýnek, T., Glendinning, I. (2015). Impact of Policies for Plagiarism in Higher Education Across Europe: Results of the Project. Acta Universitatis Agriculturae et Silviculturae Mendelianae Brunensis, 63(1), 207-216.

Glendinning, I., Foltýnek, T., Demoliou, C., Józwik, K., Stabingis, L. (2013). Comparison of policies for academic integrity in higher education across the European Union. Available from: http://ippheae.eu/images/results/2013_12_pdf/D2-300\%20EU\%20IPPHEAE\%20CU\%20Survey\%20EU-wide\%20report.pdf. Accessed 5 March 2020.

Ives, B., Alama, M., Mosora, L. C.,Mosora, M., Grosu-Radulescu, L., Clinciu, A. I., Cazan, A.M., Badescu, G., Tufis, C., Diaconu, M., \& Dutu, A. (2017). Patterns and predictors of academic dishonesty in Romanian university students. Higher Education, 74(5), 815-831.

Kaptein, M. (1998). Ethics Management. Auditing and Developing the Ethical Content of Organizations, Dordrecht: Kluwer Academic Pub.

Macfarlane, B., Zhang, J., \& Pun, A. (2014). Academic integrity: a review of the literature. Studies. Higher Education, 39(2), 339-358.

McCabe, D.L., Butterfield, D., \& Trevino, L.K. (2012). Cheating in college: Why students do it and what educators can do about it. Johns Hopkins University Press, Baltimore, MD.

Okada, A., Whitelock, D., Holmes, W., \& Edwards, C. (2019). E-authentication for online assessment: A mixed method study. British Journal of Educational Technology, 50(2), 861-875.

Order of the Ministry of National Education No. 3131/2018 regarding inclusion in the curricula, for all university study programs organized in higher education institutions in the national education system, of ethics and academic integrity courses. Available from: https://www.edu.ro/sites/default/files/ordin\%203131-2018docx.pdf. Accessed 10 October 2019.

Rettinger, D. A., \& Kramer, Y. (2009). Situational and personal causes of student cheating. Research in Higher Education, 50, 293-313.

Teixeira, A., Rocha, M. (2010). Cheating by economics and business undergraduate students: an exploratory international assessment. Higher Education, 59(6), 663-701. 